\title{
HEART RATE AND LOWER LIMB MUSCLE ACTIVITY ON CYCLE ERGOMETER
}

FREQUENNCIA CARDÍACA EATIVIDADEMUSCULARDOS MEMBROS INFERIORES EM CICLOERGÔMETRO

FRECUENCIA CARDÍACA Y ACTIVIDAD MUSCULARDE LOS MIEMBROS INFERIORES EN CICLOERGÓMETRO

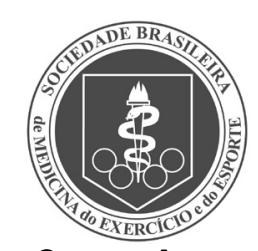

Original Article

ARTIGo ORIGINAL

Artículo Original
Paulo Rui de Oliveira' (ID

(Electrical Engineer)

Robson Dias Scoz' (DD (Physiotherapist)

Bruno Mazziotti Oliveira Alves ${ }^{1,4}$ (DD (Physiotherapist)

Thiago Rosa de Mesquita' (ID (Physiotherapist)

Rubens Alexandre da Silva Junior 2,3 (ID (Physiotherapist)

Edgar Ramos Vieira ${ }^{5}$ (D)

(Physiotherapist)

Cesar Ferreira Amorim 1,3,5 (DD

(Electronic Engineer)

1. Universidade da Cidade de São Paulo (UNICID), Master's and Doctorate Program in Physiotherapy, São Paulo, SP, Brazil. 2. Universidade Norte do Paraná (UNOPAR), Center for Research in Health Sciences, Functional Evaluation Laboratory and Human Motor Performance (LAFUP),

Londrina, PR, Brazil.

3. Physical Therapy Program of McGill University offered by extension at Universidé du Québec à Chicoutimi (UQAC), Department of Health Sciences, Saguenay, Quebec, Canada.

4. Paris Saint-Germain Department of Physical Therapy and

Biomechanics, Paris Saint-Germain

Football Club, Paris, France.

5. International University (FIU),

Physical Therapy Departments,

Wertheims' Colleges of Nursing and Health Sciences and Medicine, Miami, Florida, United States.

\section{Correspondence:}

César Ferreira Amorim

Universidade Cidade de São Paulo (UNICID), Programa de Mestrado e Doutorado em Fisioterapia. Rua Cesário Galero, 448/475, Tatuapé, São Paulo, SP, Brazil. 03071-000. cesar.amorim@unicid.edu.br

\begin{abstract}
Introduction: Muscle activity in the pedal stroke movement on a cycle ergometer can be measured by surface electromyography, as an effective and improved method for studying muscle action and objectively determining the different action potentials of the muscles involved in specific movements. Heart rate behavior is an important factor during exercise with load. Objective: To identify heart rate behavior and pattern of muscle activity of the rectus femoris and vastus medialis in healthy subjects in the pedaling dynamic at different loads, submaximal test, on an instrumented cycle ergometer. Methods: 20 healthy adults were evaluated. Heart rate measurement was performed, together with electromyographic analysis, in the time domain, of the rectus femoris and vastus medialis muscles during incremental exercise of the lower limbs on the cycle ergometer. Results: Heart rate behavior presented significant difference for $p \geq 0.05$ in relation to increased loads. The EMG signal intensity from the vastus medialis muscle (normalized RMS value) in each quadrant of the pedaling cycle showed significant difference for $\mathrm{p} \geq 0.05$ in relation to quadrants I, II and IV and significant difference for $p \geq 0.05$ in relation to quadrants III and IV. In the rectus femoris (RF) muscle, there was significant difference for $p \geq 0.05$ in relation to quadrants I, II and IV and significant difference for $p \geq 0.05$ in relation to quadrants I, II and III. Conclusion: An increase in heart rate proportional to the increase in load was observed, as well as an increase in the amplitude of the electromyographic signal proportional to the increase in load. It was possible to identify the pattern of muscle activation in the studied quadrants during pedal stroke movements, independent of load. Level of evidence III; Study of non-consecutive patients; without uniform application of the "gold" standard reference.
\end{abstract}

Keywords: Heart rate; Surface electromyography; Rectus femoris; Vastus medialis.

\section{RESUMO}

Introdução: A atividade muscular no gesto motor da pedalada no cicloergômetro pode ser mensurada por meio da eletromiografia de superficie. A eletromiografia de superfície tem sido um método efetivo e aprimorado para estudar a ação muscular, determinando com objetividade os diferentes potenciais de ação dos músculos empenhados em movimentos específicos. O comportamento da frequência cardíaca tem relação importante durante o exercício com carga. Objetivo: Identificar o comportamento da frequência cardiaca e o padrão da atividade muscular do reto femoral e vasto medial em indivíduos saudáveis na dinâmica da pedalada em diferentes cargas, teste submáximo, no cicloergômetro instrumentado. Métodos: Foram avaliados 20 adultos saudáveis, realizando-se a mensuração da frequência cardíaca e a análise eletromiográfica no domínio do tempo dos músculos reto femoral e vasto medial durante o exercício incremental dos membros inferiores em cicloergômetro. Resultados: O comportamento da frequência cardíaca apresentou diferença significante para $p \geq 0,05$ com relação ao incremento das cargas. A intensidade do sinal EMG do músculo vasto medial (valor RMS normalizado) em cada quadrante do ciclo da pedalada mostrou diferença significativa para $p \geq 0,05$ com relação aos quadrantes I, II e IV e diferença significativa para $p \geq 0,05$ com relação aos quadrantes III e IV. No músculo reto femoral (RF) verificou-se diferença significativa para $p \geq 0,05 \mathrm{com}$ relação aos quadrantes I, II e IV e diferença significativa para $p \geq 0,05$ com relação aos quadrantes I, II e III. Conclusão: Constatou-se aumento da frequência cardíaca proporcional ao incremento das diferentes cargas e também se evidenciou um aumento na amplitude do sinal eletromiográfico proporcional ao incremento da carga. Foi possível identificar o padrão da ativação dos músculos com relação ao ciclo da pedalada nos quadrantes estudados, independentemente do nível da carga. Nível de evidência III; Estudo de pacientes não consecutivos; sem padrão de referência "ouro" aplicado uniformemente.

Descritores: Frequência cardíaca; Eletromiografia; Reto femoral; Vasto medial.

\section{RESUMEN}

Introducción: La actividad muscular en el gesto motor de la pedaleada en el cicloergómetro se puede medir por medio de la electromiografía de superficie. La electromiografía de superficie ha sido un método efectivo y mejorado para estudiar la acción muscular, determinando con objetividad los diferentes potenciales de acción de los músculos empeñados en movimientos específicos. El comportamiento de la frecuencia cardíaca tiene relación importante durante el ejercicio con carga. Objetivo: Identificar el comportamiento de la frecuencia cardíaca y el patrón de la actividad muscular del recto femoral y vasto medial en individuos en la dinámica de la pedaleada en el cicloergómetro 
instrumentado. Métodos: Se evaluaron 20 adultos saludables, realizándose la medición de la frecuencia cardíaca y el análisis electromiográfico en el dominio del tiempo de los músculos recto femoral y vasto medial durante el ejercicio incremental de los miembros inferiores en cicloergómetro. Resultados: El comportamiento de la frecuencia cardiaca presentó una diferencia significativa para $p \geq 0,05$ con relación al incremento de las cargas. La intensidad de la señal EMG del músculo vasto medial (valor RMS normalizado) en cada cuadrante del ciclo de la pedaleada mostró diferencia significativa para $p \geq 0,05$ con relación a los cuadrantes I, II y V y diferencia significativa para $p \geq$ 0,05 con relación a los cuadrantes III y IV. En el músculo recto femoral (RF) se verificó diferencia significativa para $p$ $\geq 0,05$ con relación a los cuadrantes I, II y IV, y diferencia significativa para $p \geq 0,05$ con relación a los cuadrantes I, II y III. Conclusión: Se constató aumento de la frecuencia cardiaca proporcional al incremento de las diferentes cargas y también se evidenció un aumento en la amplitud de la señal electromiográfica proporcional al incremento de la carga. Fue posible identificar el patrón de la activación de los músculos con relación al ciclo de la pedaleada en los cuadrantes estudiados, independientemente del nivel de la carga. Nivel de evidencia III; Estudio de pacientes no consecutivos; sin patrón de referencia "oro" aplicado uniformemente.

Descriptores: Frecuencia cardíaca; Electromiografía; Reto femoral; Vasto medial.

\section{INTRODUCTION}

Scientific evidence points out that exercising physical activity and also physical fitness exercises are factors that contribute to the improvement and / or maintenance of human health, indicating that its regularity and adequate dosage provide benefits for physical and mental health, for people in all the ages. It is also an important and determining factor in physical and psychological health. Recovery processes in pathological interventions in individuals are also accelerated with the proper practice of these activities, as well as being adequate means for disease prevention, improving health and well-being, promoting social interaction and integration ${ }^{1,2}$.The performance of physical exercise also depends on the functional status of the respiratory, cardiovascular andmuscle skeletal ${ }^{3,4}$.

For aerobic exercise, studies prove the effectiveness and benefits of suggestions from the American College of Sports Medicine (ACSM) and the American Heart Association (AHA) that recommend at least 30 minutes of moderate physical activity, five days a week or 20 minutes of vigorous activity three days a week ${ }^{5,6}$.

Cycling is an activity that requires synchronized movements of multiple joints to generate propulsion by transferring the force produced by the lower limbs during the pedaling cycle to the pedal. The exercise bike is generally used as a form of aerobic exercise for weight loss, cardiac rehabilitation and exercise testing ${ }^{7}$.

In cycling kinetics, you can divide the pedal cycle into two phases: propulsion and recovery, shown in Figure 01. The propulsion phase, where the cyclist applies the greatest force on the pedal, occurs from $0^{\circ}$ to $180^{\circ}$, from $180^{\circ}$ to $360^{\circ}$ the recovery phase of the rotation of the

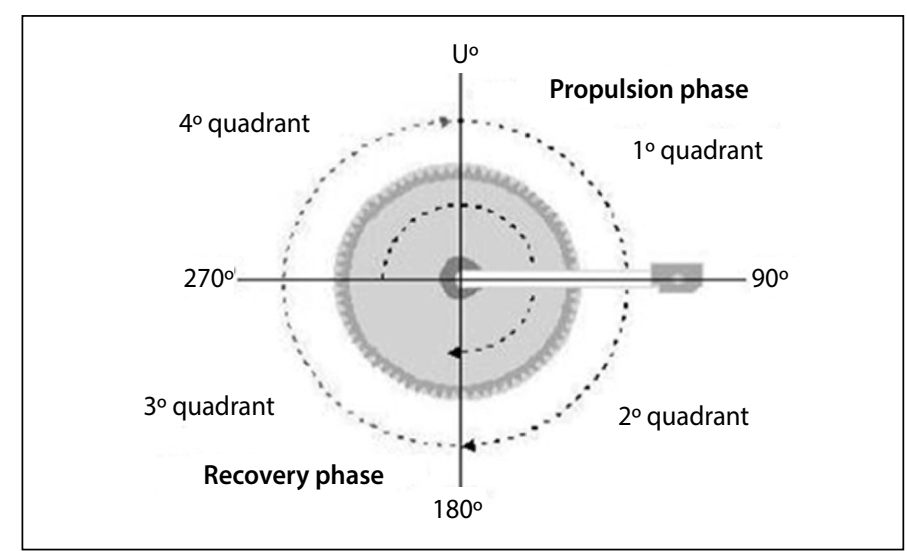

Figure 1. Pedaling Phases and Quadrants (adapted of Broker\&Gregor, 1991). sailfoot takes place, that is, when the left pedal is in the propulsive phase, the right pedal is in the recovery phase ${ }^{8}$.

The quality of the pedaling depends on the different settings of the bicycle (saddle height, sailboat size, frame size, etc.), the position adopted by the cyclist, the gear ratio and the pedaling technique. The workload and pedaling cadence also have a direct influence on muscle activity ${ }^{9}$.

Surface electromyography (EMGs) is an important technique for analyzing the structure and functioning of motor units, the electrical behavior in a musculature, identifying the activation of muscles in certain movements and also assessing muscle fatigue ${ }^{10-15}$.

The electromyographic signal is the capture of the action potential of the muscle produced during muscle contraction, making it possible to observe the recruitment of motor units. The signals are captured and shown as graph records ${ }^{10,11,13-15}$.

Detailed biomechanical analyzes of the lower limb during cycling were performed, demonstrating the intense activity of the rectus femoris muscle during the process, making it an indicator of muscle activity in cycling ${ }^{16}$.

The objective of the present study was to identify the heart rate behavior and pattern of muscle activity of the rectus femoris and vastus medialis in healthy individuals in the pedaling dynamics at different loads, submaximal test, in the instrumented ergometer cycle, with the hypothesis of increasing the amplitude of the electromyographic signal of the vastus medialis and rectus femoris muscles, proportional to the increase in load.

\section{METHODS}

\section{Design}

This is an observational cross-sectional study, in which heart rate and electromyographic signals from the rectus femoris and vastus medialis muscles of the dominant lower limb of healthy individuals were evaluated during the cycle of pedaling at different loads. It was carried out at the Movement Analysis Laboratory of the UniversidadeCidade de São Paulo - UNICID.

All signals have already been collected following all ethical principles for research with humans as established by the Declaration of Helsinki, in accordance with the study "Behavior of the Electrical Activity of the Muscles of the Lower Limbs involved in the dynamics of pedaling on a cycloergometer ${ }^{\prime \prime}$, approved byethics committee of Universidade Cidade de São Paulo - UNICID, registry \#910041. 
The sampling size calculation applied a two-tailed $\mathrm{T}$ test for independent samples, with type I error of 5\%, type II error of 20\%, power of $80 \%$ and effect size of $30 \%$, thus obtaining a calculated sample of 25 individuals.

After completing and signing the Informed Consent Form, the selected individuals, according to the eligibility criteria, underwent anthropometric assessments, and measurements of heart rate, respiratory rate, oxygen saturation and blood pressure.

Personal information was noted and the Physical Activity Readiness Questionnaire(Par-Q) $)^{17}$, e Baecke ${ }^{18-20}$, were filled out to classify the individual as sedentary or physically active. ${ }^{21}$

Data from twenty individuals from a previous study were analyze$d^{\prime}$ and divided into two groups. A physically active group (10 individuals) and a sedentary group (10 individuals).

The eligibility criteria were a young, healthy adult, of both sexes, aged between 18 and 36 years, with no previous history of any musculoskeletal disorder.

Individuals diagnosed with musculoskeletal disorders that could interfere with electromyographic assessment, individuals with cognitive impairment preventing the understanding of the procedures and those who for some reason are unable to perform incremental exercise on the lower limbs cycloergometer were excluded.

\section{Procedures}

All participants underwent physical evaluation, heart rate analysis, electromyographic analysis of the rectus femoris and vastus medialis muscle and incremental exercise on the lower limbs cycloergometer. They were also submitted to physical examination to check vital signs, a necessary condition for performing the exercises.

An anamnesis form was filled out containing personal information and demographic data (Table 1).

The data from the electromyographic signals of the rectus femoris and vastus medical muscles were collected in the region of greatest electrical activity, following the recommendations of the International Society of Electrophysiology and Kinesiology (ISEK) and SENIAN, regarding the size of the contact area of the electrodes, positioning on the muscles and the distance between the pairs ofelectrodes ${ }^{22}$.

In addition to the evaluation of the lower limb muscles, the heart rate synchronized to the EMG signals of the intensity of the imposed load, speed and cadence of the pedaling was recorded, to observe the behavior of the latter, in relation to the different loads during the incremental exercise.

Table 1. Characteristics and demographic variables of the participants.

\begin{tabular}{c|c|c}
\hline Variable & $\begin{array}{c}\text { Group } \\
\text { Physically } \\
\text { Active }\end{array}$ & $\begin{array}{c}\text { Group } \\
\text { Sedentary }\end{array}$ \\
\hline Gender & & $5(50)$ \\
\hline Female & $5(50)$ & $5(50)$ \\
\hline Male & $5(50)$ & $23,1(4,23)$ \\
\hline Age (year) & $27,5(5,29)$ & $1,7(0,09)$ \\
\hline Height (meter) & $1,73(0,1)$ & $75,78(21,77)$ \\
\hline Body weight $(\mathrm{kg})$ & $74,75(13,03)$ & $25,99(6,63)$ \\
\hline IMC & $25,08(3,65)$ & $1(10)$ \\
\hline Smoker & & $9(90)$ \\
\hline Yes & $1(10)$ & $10(100)$ \\
\hline No & $9(90)$ & $0(0)$ \\
\hline Par-Q & & $7,37(0,81)$ \\
\hline Apt & $10(100)$ &
\end{tabular}

After evaluating the maximum voluntary contraction, an incremental exercise was performed following the Billat Protocol (2001), where the speed was kept constant for 3 minutes and the load was increased so that the power was increased by 25 Watts.

All signals were collected simultaneously and analyzed using the software EMGLab V1.1 - EMG System do Brasil23.

The system was implemented in order to follow the trace related to the cycloergometer load, making it possible to carry out the increments in the load accurately.

The data were analyzed using the quantitative method in the domain of amplitude. The values of the electrical activities of the muscles ( $\mu \mathrm{V}$ RMS) were individually normalized by the maximum voluntary contraction (CVM).

To obtain the RMS averages of the evaluated muscles, mobile windows were used every $200 \mathrm{~ms}$, in the studied loads. The results were expressed as mean and standard deviation.

The load imposed on the pedal of the cycloergometer was measured through a force transducer and the measurements of load increase were synchronized to the other collected signals.

\section{Assessment of Maximum Voluntary Contraction}

Due to the known variability of the signal, not only between people, but also between attempts, different standardization techniques have been developed to reduce this variability, being the maximum voluntary contraction (CVM), one of the known ways, which uses the highest value found in a contraction maximum voluntary, for the muscles in question correlating with the signals measured during the data extraction ${ }^{14,24,25}$.

\section{Incremental Exercise Protocol}

The protocol applied during the exercise test should consider the purpose of the assessment, the specific expected results, and the characteristics of the individual being assessed, such as age and symptoms.

Larger increments protocols, such as Bruce, Billat and Ellestad, are more suitable for research with young individuals and/or physically active. ${ }^{26}$

After the evaluation of the maximum voluntary contraction, the participant already positioned on the exercise bike, previously adjusted, with the electrodes positioned, performed the incremental exercise following the Billat Protocol (2001).

The choice of this protocol was based on a study by Azevedo (2010) that recommends that the stages that make up the incremental test must be long enough for stabilization of blood lactate concentrations to occur after each new load increase, that is, the dynamic balance between blood and muscle lactate. It is suggested that each stage lasts between 3 and 10 minutes $^{26}$.

The authors indicate the following loads and increment times: 10 Watts (W) and duration of 2 minutes for each stage; $20 \mathrm{~W}$ every $3 \mathrm{mi}-$ nutes; $30 \mathrm{~W}$ every 4 minutes; $40 \mathrm{~W}$ every 4 minutes and 45 seconds; 50 W every 5 minutes $^{26}$.

Therefore, the choice of the Billat protocol is more appropriate in relation to other incremental protocols, since it performs a $25 \mathrm{~W}$ increment in the load of the cycloergometer, every 3 minutes, maintaining a constant speed, on average $22.5 \mathrm{Km} / \mathrm{h}$, until the subjective fatigue reported by the individual under evaluation.

Taking into account that the Billat Protocol is performed until subjective fatigue, for the classification of the subjective perception of effort, 30 seconds before the increase in the load, a Borg ${ }^{27,28}$ was answered by each individual, peripheral oxygenation was measured by a pulse oximeter, and the heart rate was recorded. Symptom recommendations for test interruption according to American College Sports Medicine (2007) were also followed. 
After performing the incremental protocol, the vital signs: heart rate, respiratory rate, oxygen saturation and blood pressure were measured and recorded again only as feedback on the volunteer's physical situation (Table 2).

\section{Statistical Analysis}

Continuous variables are expressed as means, standard deviation (SD) and RMS (Root Mean Square) and the data were subjected to a normality test. Through the analysis of variance ANOVA (one-way), it was possible to observe that the VM Muscle (vast medial) presents significant difference for $\mathrm{p}^{3} 0.05$ in relation to quadrants I, II and IV. It also presents a significant difference for $\mathrm{p}^{3} 0.05$ in relation to quadrants III and IV (Table 3). For the RF muscle (rectus femoris), a significant difference can be observed for $\mathrm{p}<0.05$ in relation to quadrants I, II and IV. It also presents a significant difference for $p<0.05$ in relation to quadrants I, II and III (Table 4). Heart rates showed a significant difference for $p<0.05$ in relation to the different loads (Table 5).

\section{RESULTS}

Table 3 shows that the heart rate is dependent on the increased load imposed during pedaling.

The behavior of the heart rate as a function of the imposed loads, is depicted in Figures 2 and 3, indicating the direct relationship between them.

Table 2. Clinical signs during the test.

\begin{tabular}{c|c|c}
\hline Variable & $\begin{array}{c}\text { Group } \\
\text { Physically } \\
\text { Active }\end{array}$ & $\begin{array}{c}\text { Group } \\
\text { Sedentary }\end{array}$ \\
\hline Initial HR (bpm) & $76,8(7,35)$ & $75(11,42)$ \\
\hline RR inicial (bpm) & $16,3(2,95)$ & $17,3(2,75)$ \\
\hline $\mathrm{SpO}_{2}$ inicial (\%) & $96,4(0,7)$ & $96,5(1,08)$ \\
\hline Final HR (bpm) & $143,3(20,97)$ & $137,6(20,94)$ \\
\hline Final RR (bpm) & $23,3(3,59)$ & $24,8(3,68)$ \\
\hline SpO final (\%) & $96,2(0,79)$ & $96,4(1,17)$ \\
\hline
\end{tabular}

Continuous variables are expressed as mean and standard deviation (SD), HR (Heart Rate); FR (Respiratory Rate) SpO2 (Oxygen Saturation).

Table 3. Average heart rate (MFC) during the cycle of pedaling at different loads.

\begin{tabular}{c|c|c|c|c|c}
\hline P valor & $\begin{array}{c}\text { MFC 1C } \\
\text { (bpm) }\end{array}$ & $\begin{array}{c}\text { MFC 2C } \\
\text { (bpm) }\end{array}$ & $\begin{array}{c}\text { MFC3C } \\
\text { (bpm) }\end{array}$ & $\begin{array}{c}\text { MFC 4C } \\
(\mathbf{b p m})\end{array}$ & Effect size \\
\hline$p \geq 0,05$ & $78 \pm 7,74$ & $108 \pm 13,54$ & $127 \pm 17,76$ & $140 \pm 18,02$ & 0,435 \\
\hline
\end{tabular}

Continuous variables are expressed as mean and standard deviation (SD), heart rate in the four loads ( $1 C, 2 C, 3 C, 4 C$ ). Statistical significant difference for $p \geq 0.05$ in relation to the four loads.

Table 4. Electrical activity of the vastus medial muscle (MV) during the four quadrants of pedaling at different loads.

\begin{tabular}{c|c|c|c|c|c}
\hline Quadrant & VM1C $(\boldsymbol{\mu V})$ & VM2C $(\boldsymbol{\mu V})$ & VM3C $(\boldsymbol{\mu V})$ & VM4C $(\boldsymbol{\mu V})$ & Effect size \\
\hline$\left.\right|^{\$}$ & $113.78 \pm 9,04$ & $122.87 \pm 9,82$ & $147.04 \pm 11,76$ & $147.09 \pm 11,76$ & 0,427 \\
\hline$\|$ & $79.69 \pm 6,37$ & $100.90 \pm 8,07$ & $103.26 \pm 8,26$ & $67.82 \pm 5,42$ & - \\
\hline$\|^{\&}$ & $5.96 \pm 0,47$ & $5.89 \pm 0,47$ & $6.44 \pm 0,51$ & $6.99 \pm 0,55$ & 0,309 \\
\hline IV & $49.83 \pm 3,98$ & $56.33 \pm 4,50$ & $56.52 \pm 29,11$ & $63.95 \pm 5,11$ & - \\
\hline
\end{tabular}

Continuous variables are expressed as mean and standard deviation (SD), RMS (Root Mean Square) VM (vast medial). \&: significant difference for $p \geq 0.05$ in relation to quadrants I, II and IV. \$ significant difference for $p \geq 0.05$ in relation to quadrants III and IV.

Table 5. Electrical activity of the rectus femoris (RF) muscle during the four quadrants of pedaling at different loads.

\begin{tabular}{c|c|c|c|c|c}
\hline Quadrant & RF1C $(\boldsymbol{\mu V})$ & RF2C $(\boldsymbol{\mu V})$ & RF3C $(\boldsymbol{\mu V})$ & RF4C $(\boldsymbol{\mu V})$ & Effect size \\
\hline$I$ & $19.96 \pm 1,59$ & $15.57 \pm 1,24$ & $24.40 \pm 1,94$ & $26.95 \pm 2,15$ & - \\
\hline$\|$ & $11.33 \pm 0,90$ & $14.53 \pm 1,16$ & $18.86 \pm 1,50$ & $17.75 \pm 1,42$ & - \\
\hline$\|^{\#}$ & $4.68 \pm 0,37$ & $4.41 \pm 0,35$ & $4.67 \pm 0,37$ & $5.21 \pm 0,41$ & 0,148 \\
\hline$I^{@}$ & $22.20 \pm 1,77$ & $27.28 \pm 2,18$ & $37.35 \pm 2,98$ & $46.00 \pm 3,68$ & 0,475 \\
\hline
\end{tabular}

Continuous variables are expressed as mean and standard deviation (SD), RMS (Root Mean Square), RF (rectus femoris). \#: Significant difference for $p \geq 0.05$ in relation to quadrants I, II and IV. @: significant difference for $p \geq$ 0.05 in relation to quadrants I, II and III.

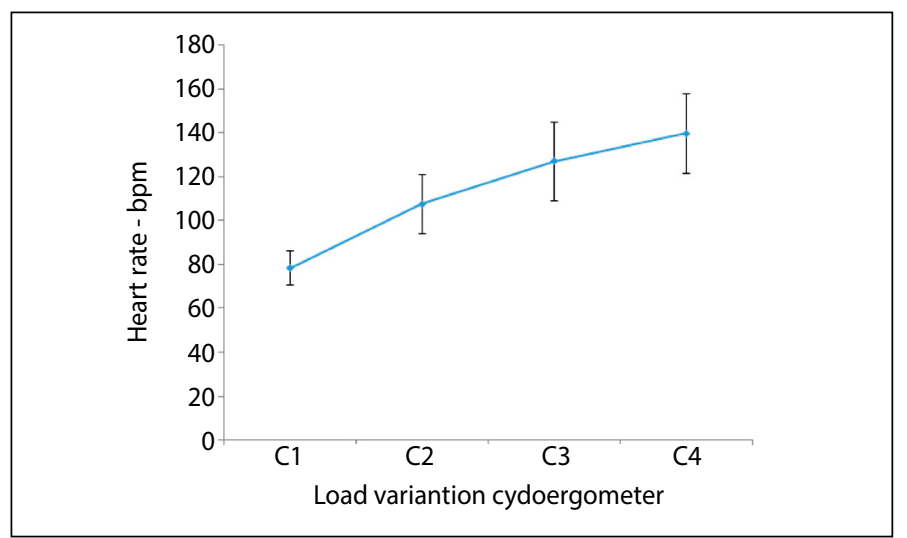

Figure 2. Mean and standard deviation of heart rate behavior in relation to the load variation controlled by the instrumented cycloergometer.

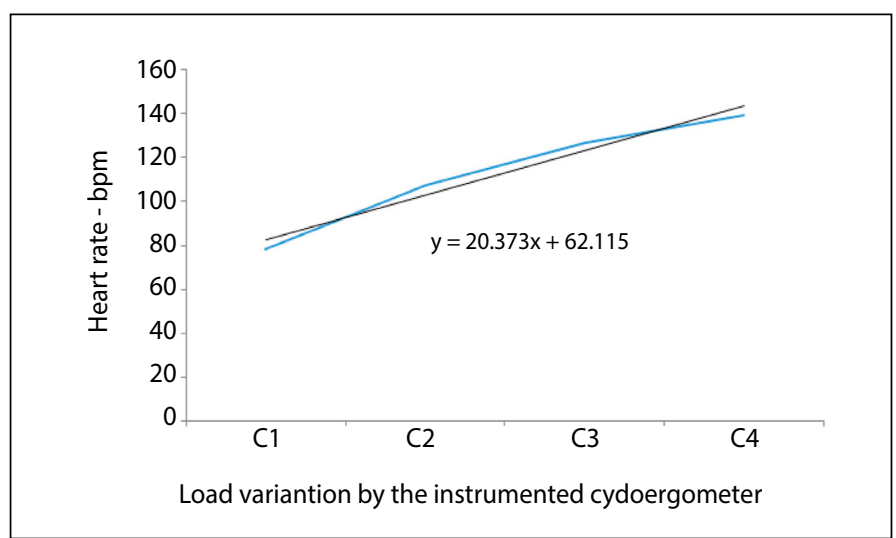

Figure 3. Linearization of heart rate behavior with load variation controlled by the instrumented cycloergometer.

In Table 4, it can be seen that there was a more significant activation of the vastus medialis muscle during the first quadrant of the pedaling in the four load increments.

Table 5 shows that there was a greater activation of the rectus femorismuscle during the fourth quadrant of pedaling in the four load increments.

\section{DISCUSSION}

This study, being performed on an instrumented cycloergometer, allowed total control of the participant's movement through heart rate, electrical activity (EMG) of the vastus medialis and rectus femoris muscles in contraction during movement at different loads. All signals were effectively synchronized from the control of imposed loads, pedal cadence, speed, EMG muscle contraction, according to the Billat Protocol. This minimizes the influence of the mechanical effect of the movement, as in the conventional cycloergometer there may be some difficulty in maintain the pedaling cadence throughout the exercise and speed control, especially with the progressive increases in the load imposed on the movement of the pedals.

The use of surface electromyography in the time domain allowed to monitor the muscle activation of the rectus femoris and vastus medialis during the cycle of pedaling. Understanding that each muscle has an important function in the pedaling movement, acting in a different phase of the same, it was decided to analyze the magnitude of the EMG signal (normalized RMS value) in each quadrant of the pedaling cycle.

Hug e Dorel ${ }^{29}$, in the comparison between groups, it showed significant differences for the magnitude of the EMG signal (normalized RMS value), when compared by quadrants of the pedal. This data could 
also be observed in this study, since the vastus medialis muscle had a greater activity in the first quadrant and the rectus femoris, had a greater activity in the fourth quadrant of the pedal.

InCandotti study ${ }^{30}$, in the first quadrant, the RMS value between the groups was significantly different for the RF and VL muscles at a rate of $90 \mathrm{rpm}$. In the third quadrant, there was no significant difference between muscle groups. In this study, there was also no significant difference in the thirdquadrant ${ }^{30}$.

According to Gregor (2000), the activity of the monoarticular muscles is more consistent when compared to the activity of the biarticular muscles, in the sense of the amount of muscle activation. It can be observed that the RF, a muscle with biarticular function that acts on both the hip and the knee, showed greater activity in the propulsion phase, acting as a knee extensor, together with the $V L$, in this same phase of the cycle. However, the RF also showed a certain degree of activation in the pedal recovery phase, acting as a hip flexor ${ }^{31}$.

Table 5 shows that the rectus femoris showed greater activity in the recovery phase, together with less activation of the vastus medialis (Table 4). However, there was an activation of this muscle in the recovery phase, more specifically during the fourth quadrant of the pedaling cycle (Figure 4) and also shown in Figure 5 which depicts the RMS and normalized averages.

With this, it can be said that the RF (rectus femoris) has an important function in the knee extensor torque, developed in the propulsion phase of the pedal cycle.

The VM and RF muscles are crucial for generating pedal forces. The vast medial produces $55 \%$ of the total power during thepropulsion phase. ${ }^{32}$

\section{Limitations}

Aiming at a reliable data collection, the study performed a quality instrumentation through a force transducer that, synchronized to the

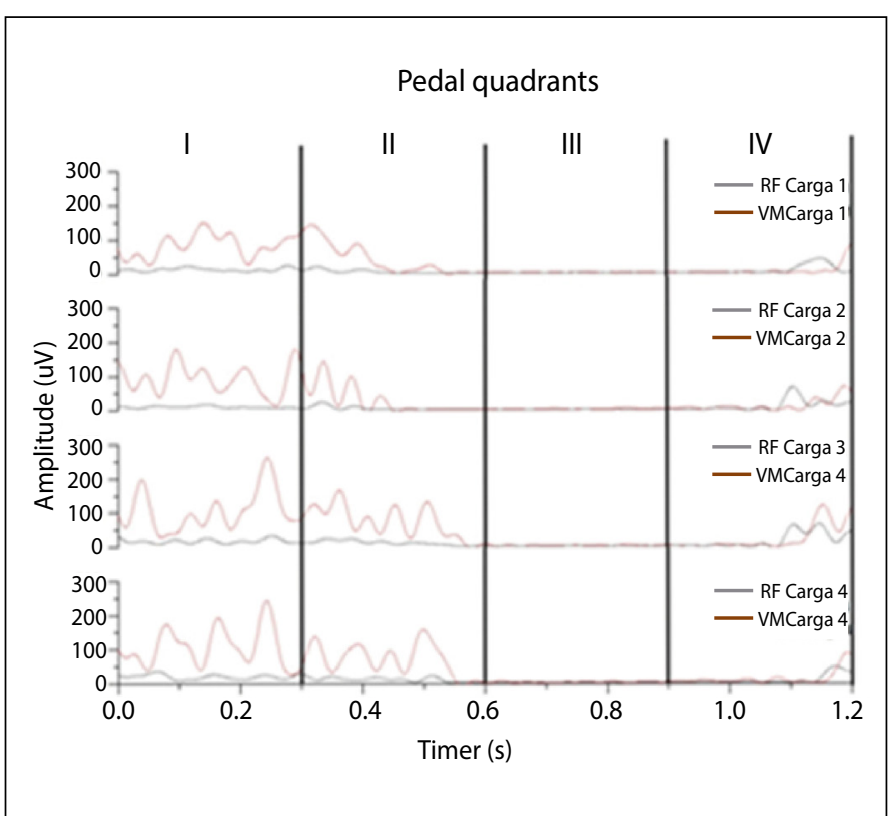

Figure 4. Electrical activity of the vastus medialis and rectus femoris muscle during the four quadrants

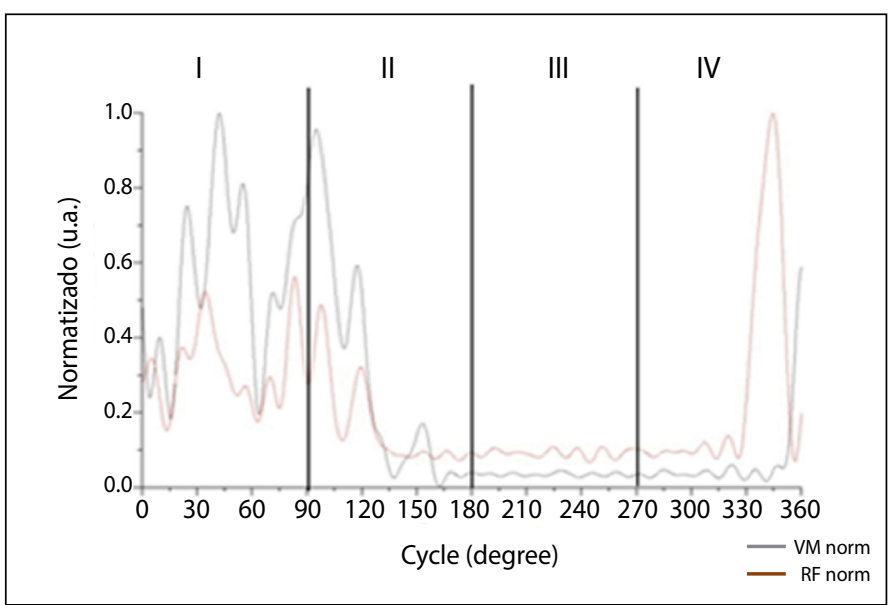

Figure 5. Average RMS of the VM and RF muscles (normalized) during the cycle of pedaling $\left(0-360^{\circ}\right)$.

acquisition module, allowed perfect adjustments for the load increase. The biological signals of the research subjects were also synchronized.

The speed control and pedaling cadence were also implemented using an electronic device designed for this purpose. In addition, to reduce the risks of physical exercise, measures were taken to find out if the participants were really able to perform the type of effort proposed.

On the other hand, no analysis of RR intervals was performed, which could provide greater power of comparison with studies found in the literature. During the collections, it was possible to notice that other muscles such as the vastus lateralis, biceps femoris, gastrocnemius and anterior tibialis play an important role in pedaling and for the study of this type of activity.

\section{CONCLUSIONS}

It was possible to identify the behavior of heart rate and its relationship with different loads imposed in an effective, instrumented and synchronized way, and the activation pattern of the vastus medial and rectus femoris muscles, showing an increase in the amplitude of the electromyographic signal proportional to the increase in the load. The pattern of muscle activation in relation to the pedaling cycle, regardless of the level of the imposed load, was also demonstrated.

Heart rate exhibits a behavior directly proportional to the increase in the load imposed on the cycloergometer.

Such characterizations have innumerable contributions to the health area, regarding their primary prevention, assisting the professional in the choice and direction of evaluations and / or training with different loads.

\section{ACKNOWLEDGEMENTS}

Dr. César Ferreira Amorim was supported by the National Council for Scientific and Technological Development (CNPq), Brazil (MCTI / CNPQ / Universal 14 / 2014- Process: 458880 / 2014-0).

All authors declare no potential conflict of interest related to this article

AUTHORS' CONTRIBUTIONS: Each author made significant individual contributions to this manuscript. PRO, CFA and BMOA: were the main collaborators in the writing of the manuscript, research project, conception, analysis and interpretation of the results; RASJ and TRM: analysis of the data, revision of the manuscripts and intellectual concept of the study; ERV and RDS: analysis of the data, writing and revision of the manuscript. All authors revised and approved the final version of the manuscript.

\section{REFERENCES}

1. Silva RC. Comportamento da atividade elétrica dos músculos de membros inferiores envolvidos na dinâmica da pedalada em cicloergômetro instrumentado. [Dissertação de Mestrado em Fisioterapia]. São Paulo: Universidade Cidade de São Paulo (UNICID); 2013.

2. Kruk J. Physical activity and health. Asian Pac J Cancer Prev. 2009;10(5):721-8.
3. Enright S, Chatham K, lonescu AA, Unnithan VB, Shale DJ. Inspiratory muscle training improves lung function and exercise capacity in adults with cystic fibrosis. Chest. 2004;126(2):405-11.

4. Lau HM, Ng GY, Jones AY, Lee EW, Siu EH, Hui DS. A randomised controlled trial of the effectiveness of an exercise training program in patients recovering from severe acute respiratory syndrome. Aust J Physiother. 2005;51(4):213-9. 
5. Garcia-Ortiz L, Grandes G, Sanchez-Perez A, Montoya I, Iglesias-Valiente JA, Recio-Rodriguez JI, et al. Effect on cardiovascular risk of an intervention by family physicians to promote physical exercise among sedentary individuals. Rev Esp Cardiol. 2010;63(11):1244-52.

6. Probst VS, Troosters T, Pitta F, Decramer M, Gosselink R. Cardiopulmonary stress during exercise training in patients with COPD. Eur Respir J. 2006;27(6):1110-8.

7. Garret JrWE, Kirkendall DT. A Ciência do exercício e dos esportes. Porto Alegre: Artmed; 2003.

8. Gregor RJ, Broker JP, Ryan MM. The biomechanics of cycling. Exercise and sport sciences reviews. 1991;19:127-69.

9. Diefenthaeler F, Bini RR, Karolczak AP, Guimarães AC. O efeito da mudança na posição do selim nos padrões de ativação muscular de ciclistas de elite. Congresso Brasileiro de Biomecânica;2005.

10. Duchene J, Goubel F. EMG spectral shift as an indicator of fatigability in an heterogeneous muscle group Eur J Appl Physiol Occup Physiol. 1990;61 (1-2):81-7.

11. Gerdle B, Larsson B, Karlsson S. Criterion validation of surface EMG variables as fatigue indicators using peak torque: a study of repetitive maximum isokinetic knee extensions. J Electromyogr Kinesiol. 2000;10(4):225-32.

12. Gosselin N, Matecki S, Poulain M, Ramonatxo M, Ceugniet F, Prefaut C, et al. Electrophysiologic changes during exercise testing in patients with chronic obstructive pulmonary disease. Muscle Nerve. 2003;27(2):170-9.

13. Hagberg M. The amplitude distribution of surface EMG in static and intermittent static muscular performance. Eur J Appl Physiol Occup Physiol. 1979;40(4):265-72.

14. Luca CJ. The Use of Surface Electromyography in Biomechanics. J Appl Biomech. 1997;13(2):135-63.

15. Masuda K, Masuda T, Sadoyama T, Inaki M, Katsuta S. Changes in surface EMG parameters during static and dynamic fatiguing contractions. J Electromyogr Kinesiol. 1999;9(1):39-46.

16. Hull ML, Jorge M. A method for biomechanical analysis of bicycle pedalling. J Biomech. 1985;18(9):631-44.

17. Thomas S, Reading J, Shephard RJ. Revision of the physical activity readiness questionnaire (PAR-Q). Can J Sport Sci. 1992;17(4):338-45.

18. Baecke JA, Burema J, Frijters JE. A short questionnaire for the measurement of habitual physical activity in epidemiological studies. Am J Clin Nutr. 1982;36(5):936-42.

19. Florindo AA, Latorre MR. Validation and reliability of the Baecke questionnaire for the evaluation of habitual physical activity in adult men. Rev Bras Med Esporte. 2003;9(3):129-35.
20. Florindo AA, Latorre MR, Jaime PC, Tanaka T, Zerbini CA. Metodologia para a avaliação da atividade física habitual em homens com 50 anos ou mais. Rev Saúde Pública. 2004;38:307-14.

21. Sardinha A, Levitan MN, Lopes FL, Perna G, Esquivel G, Griez EJ, et al. Tradução e adaptação transcultural do Questionário de Atividade Física Habitual. Rev Psiq Clin. 2010;37(1):16-22.

22. Sousa PA, Chiavegato LD, Vieira WB, Silva RAd, Carvalho MM, Oliveira PR, et al. Electromyographic pattern of respiratory muscles in young people during incremental exercise. J Exerc Sport Orthop. 2016;3(1):1-6.

23. Alves BM, Silva Jr. RA, Rosa LM, Mesquita TR, Oliveira PR, Burigo RL, et al. Postural control analysis during a standardized kick task in soccer athletes. Rev Bras Med Esporte. 2018;24(2):89-96.

24. Amorim CF, Giannasi LC, Ferreira LM, Magini M, Oliveira CS, Oliveira LV, et al. Behavior analysis of electromyographic activity of the masseter muscle in sleep bruxers. J Bodyw Mov Ther. 2010;14(3):234-8.

25. Riedi C. Avaliação eletromiográfica do desempenho muscular respiratório e periférico. [Dissertação de Mestrado]. Piracicaba: Universidade Metodista de Piracicaba; 2006.

26. Azevedo PH. Proposta de teste específico para determinação do limiar anaeróbico, limiar de compensação respiratória e máxima fase estável do lactato sanguíneo em judocas. [Tese de Doutorado]. São Carlos: Universidade Federal de São Carlos (UFSCAR); 2010.

27. Chen MJ, Fan X, Moe ST. Criterion-related validity of the Borg ratings of perceived exertion scale in healthy individuals: a meta-analysis. J Sports Sci. 2002;20(11):873-99.

28. Robertson R, Goss F, Michael T, Moyna N, Gordon P, Visich P, et al. Validity of the borg perceived exertion scale for use in semirecumbent ergometry during immersion in water. Perceptual MotSkills. 1996;83(1):3-13

29. Hug F, Dorel S. Electromyographic analysis of pedaling: a review. J electromyogr Kinesiol. 2009;19(2):182-98

30. Candotti CT. Características biomecânicas e fisiológicas da técnica da pedalada de ciclistas e triatletas. [Tese de Doutorado]. Porto Alegre: Universidade Federal do Rio Grande do Sul (UFRS); 2003.

31. Silva JC, Ekblom MM, Tarassova O, Andersson E, Rönquist G, Grundström H, et al. Effect of increasing workload on knee extensor and flexor muscular activity during cycling as measured with intramuscular electromyography. PloS One. 2018;13(8):e0201014.

32. Raasch CC, Zajac FE, Ma B, Levine WS. Muscle coordination of maximum-speed pedaling. J Biomech. 1997;30(6):595-602 